\title{
MONITORING OF STRUCTURAL COMPONENTS AND WATER BALANCE AS AN AID TO WETLAND MANAGEMENT USING GEOSPATIAL TECHNIQUES - A CASE STUDY FOR NALSAROVAR LAKE, GUJARAT
}

\author{
T.V.R. Murthy* and Sushma Panigrahy \\ EHD/ABGH/EPSA, Space Applications Centre, ISRO, Ahmedabad - 380015 \\ *Email: murthytvr@sac.isro.gov.in
}

KEY WORDS: Nalsarovar Lake, MODIS, Water balance, SRTM-DEM, Avi-fauna

\begin{abstract}
:
The hydrologic variability greatly influences the structural components of wetlands that have a great bearing on habitats for avifauna, aquatic fauna including fish etc. This paper highlights the results of a study carried out to derive changes in open-water and vegetation, and also water balance for Nalsarovar Lake, Gujarat. MODIS 8-day composite data for three consecutive years viz 2002/03, 2003/04 and 2004/05 were used to study the seasonal and inter annual dynamics of water regime in the lake. Digital elevation model derived using Shuttle Radar Topographic Mission data with interpolated bottom topography was used to generate elevation contours and compute water volume from water spread data. The reference data of 2002 (drought year) shows the maximum extent of wetland to be $8.06 \mathrm{~km}^{2}$ with emergent vegetation of recorded as $2.36 \mathrm{~km}^{2}$ and open-water as $5.70 \mathrm{~km}^{2}$. The rainfall has an impact on the preferred habitat availability for various species of avifauna and it is noted that emergent vegetation present in the lake completely dried up by summer 2002, a rainfall deficit year but revived again in the preceding year i.e. 2003 which was a good rainfall year with $46.68 \mathrm{~km}^{2}$ under emergent vegetation and $61.96 \mathrm{~km}^{2}$ under open-water. The 2002 being a drought year has shown very low reference storage $(0.256 \mathrm{MCM})$, which has shown a gradual decrease in the storage to 0.00019 MCM in March 2003. The reference storage also registered a steep increase to 18.165 MCM in October 2003 and decreased 1.264 MCM in March 2004. From this study it is evident that water level of about $9 \mathrm{~m}$ elevation at the end of the rainy season is found to be optimal for maintaining various habitats that in turn support the avifauna for the rest of the lean period.
\end{abstract}

\section{INTRODUCTION}

Wetlands are among the most productive ecosystems of the world. The interactions of physical, chemical and biological components of wetlands enable them perform multiple functions like water storage, storm protection and flood mitigation (Mitsch and Gosselink, 2000). The wetlands like natural lakes, swamps, waterlogged area play very crucial role in avifauna life cycle. Thus, wetland management though requires many parameters, hydrology is the key factor. Remote sensing data has been widely used for mapping and monitoring of various structural components of wetland like water spread, aquatic vegetation, water quality etc (Prigent et al, 2001, Ndirima, 2007). Modelling of hydrological fluctuations, water balance of wetlands like lakes, eservoirs is also being attempted with advances in satellite remote sensing. This paper highlights the use of multi temporal remote sensing data and satellite derived digital elevation model to study the surface hydrological condition and its influence on various habitat types of avifauna in an important inland lake, which is a notified bird sanctuary in India.

\section{STUDY AREA}

Nalsarovar situated between $22^{0} 40^{\prime} 00^{\prime \prime}-22^{0} 52^{\prime} 00^{\prime \prime} \mathrm{N}$ latitudes and $71055^{\prime} 00^{\prime \prime}-72^{\circ} 06^{\prime} 00^{\prime \prime} \mathrm{E}$ longitudes located amidst the semi-arid lands of Ahmedabad and Surendranagar districts of Gujarat, India is the study site (Fig.1). It falls in the 4B Gujarat-Rajwara biotic province of the semi arid biogeographical zone. Nalsarovar notified as a sanctuary under Wildlife (Protection) Act, 1972; is the largest wetland bird sanctuary in Gujarat. The avi-fauna habitat formation is highly dynamic due to changes in the water level and based on this water level and vegetation, eight habitat types have been identified (Anon., 1998, Tatu, 1995), the important ones being i) Deep open-water, ii) Shallow open-water, iii) Emergentaquatic vegetation and iv. Mud habitat.

\section{DATA USED}

The remote sensing data comprised cloud-free IRS LISS-III data closest to the last rainfall event of the season for 2002, 2003 and 2004 were used as reference. The eight-day composite reflectance data of MODIS Aqua pertaining to green, red, NIR, SWIR bands $(500 \mathrm{~m})$ from October 31 to March 30 for 2002-03, 2003-04 and 2004-05 were used to monitor the temporal changes in the wetland structural components. Actual Evapotranspiration (AET) products based on MODIS data of same period were also used.

The digital elevation data of Shuttle Radar Topographic Mission (SRTM) of NASA was used for elevation contour generation. The data is of $90 \mathrm{~m}$ resolution at the equator, with reported vertical error of less than $16 \mathrm{~m}$ (downloaded from USGS ftp site). These are available in both ArcInfo GRID and GeoTiff format to facilitate their ease of use in a variety of image processing and GIS applications. The version 4 available from August 2009 is used for this study. Field data was collected on various classes for thematic classification of remote sensing data. Sampled locations on water depth were also collected. Ancillary information on rainfall data, lake water use etc. were also collected. 


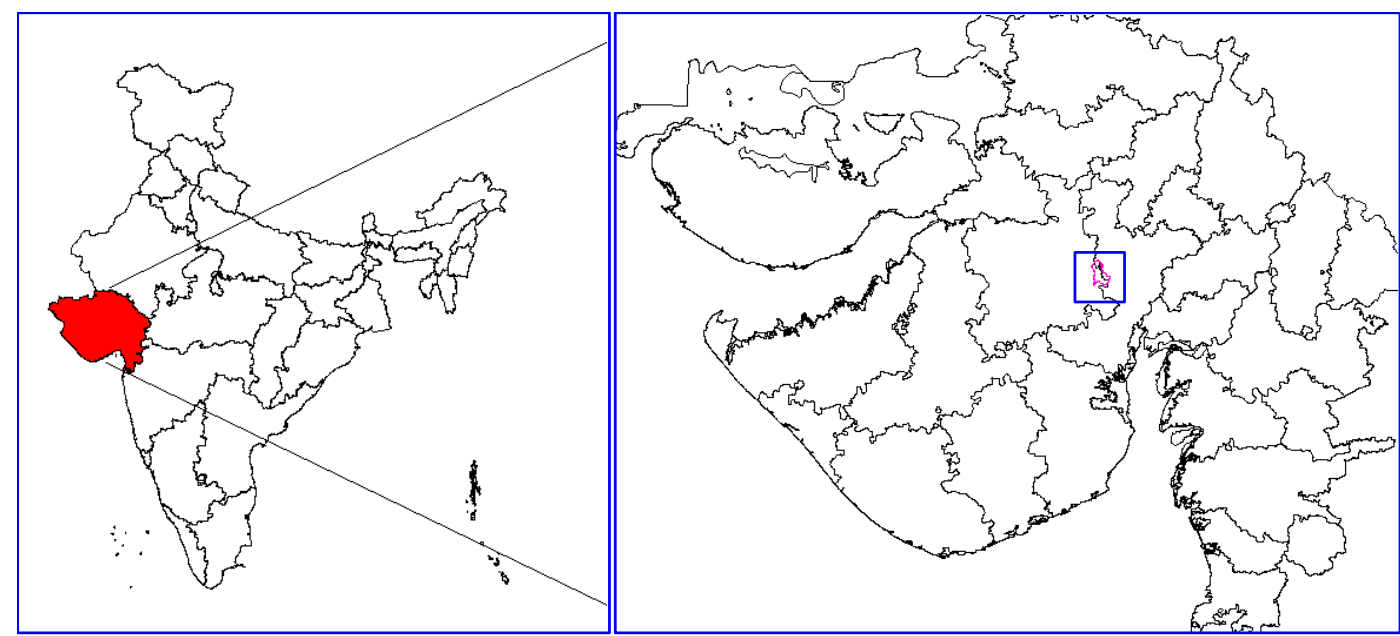

Figure 1: $\quad$ Location of Nalsarovar Lake (Gujarat, India)

\section{METHODOLOGY}

\subsection{Derivation of Wetland Structural Components}

Pre-processing of remote sensing data was done following standard techniques of geometric correction, reprojection to a standard coordinate system (Anon., 2005), multi-date data registration, conversion of digital number to radiance. This was followed by generation of various indices images such as Normalised Difference Water Index (McFeeters, 1996), Modified Normalised Difference Water Index (Hanque, 2002), Normalised Difference Pond Index (Lacaux et al, 2007) and Normalised Difference Vegetation Index (Tucker and Sellers, 1986; Townshend and Justice, 1986). These indices were then used to map the open-water spread, aquatic vegetation, terrestrial vegetation, muddy area etc as demonstrated by Murthy et al, 2009. The work was carried out using ERDAS 9.2 image processing software.

\subsection{Water Volume and Balance Estimation}

For the computation of volume of the water in the lake, one requires the aerial extent and depth. Depth was derived in an indirect way using SRTM-DEM. First the Digital elevation of the land area surrounding the lake using SRTM-DEM was calibrated using linear regression between corresponding values of elevation for the common points in the SRTM-DEM and ground data (collected from various survey maps). Since, a very good linear relationship $\left(\mathrm{R}^{2}=0.901\right)$ was obtained the SRTM data was used for the generation of elevation contours of the area.

Since, the SRTM-DEM does not give the elevation of water surface (shows no-data), the temporal change in the water spread boundary as derived from satellite data was used as elevation contour line, based on the assumption that the surface of water reaches the same height everywhere within the lake. GPS based point measurements for depth of the water were collected (during November 2005 to October 06, regularly for each month corresponding to water spread boundary) and used for the surface interpolation of bottom topography.

To account for the loss of water while computing the change in storage for water balance, actual evapotranspiration (AET) was computed using MODIS (Aqua) noontime optical and thermal data (Bhattacharya et al, 2007).
Change in storage is calculated as:

$\Delta \mathrm{S}_{1}=\mathrm{S}_{\mathrm{r}}-(\mathrm{ET}+$ Other loses $)$ for Date

$\Delta \mathrm{S}_{2}=\Delta \mathrm{S}_{1}-\left(\mathrm{ET}_{1}+\right.$ Other loses $\left._{1}\right)$ for Date $_{2} \ldots$ Date $_{\mathrm{n}}$ Where,

$\Delta \mathrm{S}_{1} \quad=$ Change in storage for date 1

$\mathrm{S}_{\mathrm{r}} \quad=$ Reference Storage

$\Delta \mathrm{S}_{2} \quad=$ Change in storage for date 2

$\mathrm{ET}_{1} \quad=$ Evapotranspiration for date 1

The volume of the water is computed for each dataset using the elevation information. Water balance $(\Delta S)$ is computed by subtracting the volume of $S_{1}$ from the reference volume $\left(S_{r}\right)$ and also accounting loses due to actual evapotranspiration (AET). As other loses like use of water for irrigation, surface/subsurface flow were not physically measured in this study, the difference barring the AET is considered as other loses.

\section{RESULTS AND DISCUSSION}

The wetland boundary, open-water spread and aquatic vegetation (emergent) could be delineated using combinations of indices images (Fig. 2).

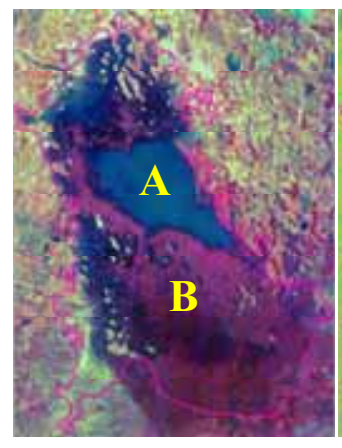

LISS III FCC (Green Red NIR)

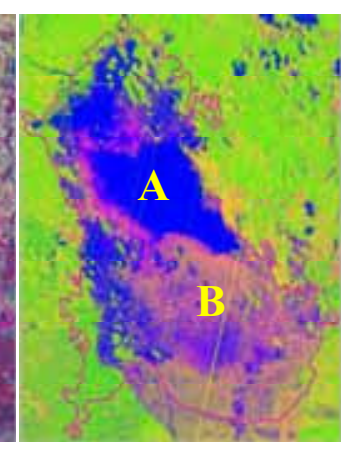

FCC of Indices (MNDWI NDPI NDVI)

\section{A: Open-water B: Emergent Vegetation}

Figure 2: IRS LISS III FCC of the Nalsarovar Lake area along with FCC of indices highlighting accurate detection of openwater and emergent vegetation areas

Nalsarovar Lake being fed through surface runoff exhibit wide fluctuations in the water spread and consequently vegetation 
spread, both seasonally and annually. Annual fluctuations are due to the change in rainfall quantity received during monsoon. Figure-3 shows the LISS III FCC corresponding to postmonsoon season (October) of the lake during a drought year (2002), and a normal monsoon year (2004). One can observe the complete drying of emergent vegetation in the drought year and revival of the same in the next year- a normal monsoon year. Similar observations have been made in other studies (Anon, 1998).

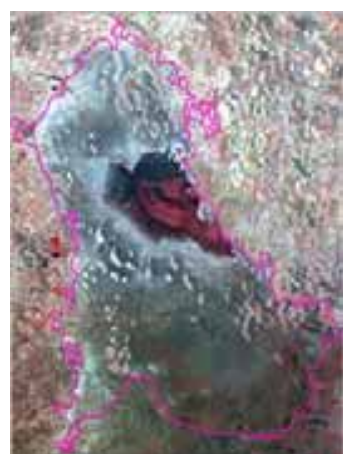

$10 / 10 / 2002$ Drought year

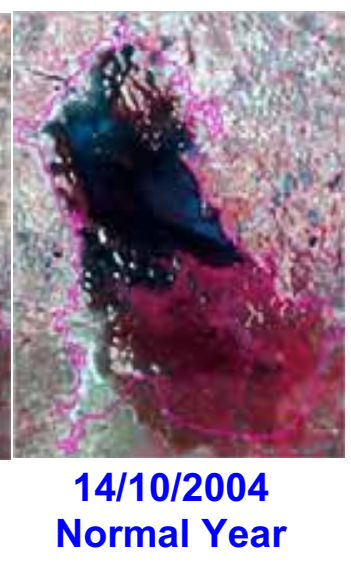

Figure 3: IRS LISS III FCC of Nalsarovar Lake area showing status of open-water and emergent vegetation areas during post-monsoon month of October in a drought year (2002) and a normal year (2003) patterns, as well as the extent of suitable foraging habitats for avifauna. Further, hydrology influences the physico-chemical and biological properties of the lake as well as macrophytes along with the fish and other animals that could be a source of food to certain avifauna. Hence, modelling the water balance is the best aid in the management of this rain fed natural Lake.

\subsection{Inter- annual Changes}

The water balance derived in this study for three years using LISS III data (2002, 2003 and 2004) of post-monsoon month (October) showed significant change from normal year to a monsoon deficit year. The year 2002 was a drought year with $240.70 \mathrm{~mm}$ of season's total rainfall. The extent of open-water and emergent vegetation in the lake during 2002 October was found to be $5.70 \mathrm{~km}^{2}$ and $2.26 \mathrm{~km}^{2}$ respectively (Table 1 ). The years 2003 and 2004 were normal-to-good rainfall years with $780 \mathrm{~mm}$ and $832 \mathrm{~mm}$ rain fall respectively. The extent of openwater and emergent vegetation in the lake during 2003 and 2004 October was $61.96 \mathrm{~km}^{2}$ and $66.04 \mathrm{~km}^{2}$ respectively, while the emergent vegetation was $46.68 \mathrm{~km}^{2}$ and $49.76 \mathrm{~km}^{2}$ respectively. Thus, one can observe that the extents of openwater and emergent vegetation have been drastically reduced during a drought year compared to a normal/good monsoon year.

\subsection{Seasonal Changes}

Lakes also are known to show seasonal dynamics. Since, this lake is a natural rain-fed lake; its water storage is in its peak during monsoon period (June-September).

It can be inferred that the flooding/inundation gradient influences the vegetation composition, distribution and growth

\begin{tabular}{|c|c|c|c|c|c|c|c|c|c|}
\hline \multirow{2}{*}{$\begin{array}{c}\text { MODIS } \\
\text { Data }\end{array}$} & \multicolumn{3}{|c|}{ Area $\left(\mathrm{km}^{2}\right) 2002-03$} & \multicolumn{3}{|c|}{ Area $\left(\mathrm{km}^{2}\right)$ 2003-04 } & \multicolumn{3}{|c|}{$\operatorname{Area}\left(\mathrm{km}^{2}\right)$ 2004-05 } \\
\hline & Wetland & $\begin{array}{l}\text { Emergent } \\
\text { Vegetation }\end{array}$ & $\begin{array}{l}\text { Open } \\
\text { Water }\end{array}$ & Wetland & $\begin{array}{l}\text { Emergent } \\
\text { Vegetation }\end{array}$ & $\begin{array}{l}\text { Open } \\
\text { Water }\end{array}$ & Wetland & $\begin{array}{l}\text { Emergent } \\
\text { Vegetation }\end{array}$ & $\begin{array}{l}\text { Open } \\
\text { Water }\end{array}$ \\
\hline 31-Oct. & 7.40 & 2.26 & 5.14 & 108.43 & 48.14 & 60.30 & 115.59 & 51.31 & 64.27 \\
\hline 08-Nov. & 7.18 & 2.15 & 5.03 & 107.74 & 48.16 & 59.58 & 114.85 & 51.33 & 63.52 \\
\hline 16-Nov. & 6.82 & 1.91 & 4.91 & 107.45 & 48.57 & 58.88 & 114.54 & 51.78 & 62.76 \\
\hline 22-Nov. & 6.36 & 1.67 & 4.69 & 107.14 & 49.23 & 57.91 & 114.21 & 52.48 & 61.73 \\
\hline 02-Dec. & 6.09 & 1.63 & 4.46 & 107.11 & 49.26 & 57.85 & 114.18 & 52.51 & 61.67 \\
\hline 10-Dec. & 5.85 & 1.62 & 4.23 & 106.81 & 50.93 & 55.87 & 113.85 & 54.29 & 59.56 \\
\hline 18-Dec. & 5.51 & 1.51 & 4.00 & 105.42 & 51.00 & 54.43 & 112.38 & 54.36 & 58.02 \\
\hline 26-Dec. & 4.83 & 1.39 & 3.44 & 104.91 & 50.93 & 53.97 & 111.83 & 54.30 & 57.53 \\
\hline 01-Jan. & 4.55 & 1.39 & 3.15 & 104.63 & 50.69 & 53.95 & 111.53 & 54.03 & 57.50 \\
\hline 09-Jan. & 4.06 & 1.16 & 2.90 & 104.23 & 50.63 & 53.60 & 111.11 & 53.97 & 57.14 \\
\hline 17-Jan. & 3.71 & 1.04 & 2.67 & 103.15 & 49.91 & 53.24 & 109.95 & 53.20 & 56.75 \\
\hline 25-Jan. & 3.25 & 0.93 & 2.33 & 102.27 & 49.36 & 52.91 & 109.01 & 52.61 & 56.40 \\
\hline 02-Feb. & 2.89 & 0.80 & 2.09 & 99.86 & 48.04 & 51.83 & 106.45 & 51.21 & 55.25 \\
\hline 10-Feb. & 2.67 & 0.69 & 1.98 & 98.37 & 47.54 & 50.83 & 104.86 & 50.67 & 54.18 \\
\hline 18-Feb. & 2.22 & 0.47 & 1.75 & 95.23 & 45.53 & 49.70 & 101.52 & 48.54 & 52.98 \\
\hline 26-Feb. & 1.74 & 0.24 & 1.51 & 91.80 & 43.98 & 47.82 & 97.86 & 46.88 & 50.98 \\
\hline 06-Mar. & 1.36 & 0.23 & 1.14 & 89.06 & 43.83 & 45.22 & 95.93 & 46.73 & 49.21 \\
\hline 14-Mar. & 1.23 & 0.22 & 1.02 & 86.87 & 41.87 & 45.00 & 93.50 & 44.63 & 48.87 \\
\hline 22-Mar. & 0.89 & 0.21 & 0.67 & 85.16 & 40.52 & 44.64 & 91.33 & 43.19 & 48.14 \\
\hline 30-Mar. & 0.82 & 0.21 & 0.60 & 83.76 & 40.05 & 43.71 & 89.45 & 42.69 & 46.75 \\
\hline
\end{tabular}

Table-1. Seasonal changes in the extent of open-water and emergent vegetation (from October to March) derived from MODIS 8 day composite data for 3-years.

Thus September-October in general is the peak water storage period. There after, it starts declining, and the lowest storage period is attained during May-June. High temporal 8 day composite MODIS data is thus very suitable to study the seasonal dynamics of this lake. Results showed significant seasonal fluctuation in the extent wetland extent, open-water and emergent vegetation in the lake. The total wetland area shows a gradual decrease from October to March in all the 
years (normal as well as rainfall deficit year) as shown in Table-1. Similar trend was observed with extent of open-water. However, in case of emergent vegetation, in normal years (2003, 2004) one observes a gradual increase from October early January and decrease there after. This was mainly due to the fact that the vegetation growth takes place in areas with receded water, and as the saturated areas start drying up after January with increase in temperature, the vegetation declines and reaches its minima by March end. However, in rainfall deficit year (2002), one observes gradual decrease of vegetation also.

\subsection{Water balance}

Relation between the elevation and water spread area of the lake was found to be best explained by the logarithmic fit with $\mathrm{R}^{2}=0.9489$. The volume of water thus computed was converted to storage accounting for the AET and other losses. Results showed gradual decrease of water storage from October to March during all the years. However, the peak storage of the lake registered very significant reduction in the drought year. During 2002-03, which is one of the worst monsoon years, the storage during October (2002) was 0.256 million cubic meters (MCM) got reduced to $0.00019 \mathrm{MCM}$ (Table 2) by March
(2003).During 2003-04, the storage in October was 18.165 MCM and reduced to 10.724 MCM by March. During 2004-05, which received maximum rainfall, the storage in October was 20.936 MCM that was reduced to 1.997 MCM by March.

Thus, one can infer that drastic seasonal reduction of water storage in the lake from post-monsoon to summer, strongly characterising the rain-fed water balance of this shallow lake. Since, the amount as well as depth gradient of water available in the lake is decisive in the modelling of optimal habitats of species of avifauna. Simulation of water spread using elevation contour of the lake was carried out. The results showed that beyond $10.5 \mathrm{~m}$ elevation, the lake water overflows into the Bhogava River through surface drainage present in the southern part of lake. Thus, water storage at about $9 \boldsymbol{m}$ elevation at the end of the rainy season is optimal to sustain various habitats that support the avifauna for the rest of the season. If a canal is envisaged to join Nalsarovar Lake with the Sardar Sarovar Project Canal passing through the catchment is expected to bring certain positive impacts on the wetland i) Reduction in the salinity of lake water, ii) part of the lake would become perennial and iii) Increase in submergence area leading to conducive for prolonged development of habitats for certain species of waterfowl.

\begin{tabular}{|c|c|c|c|c|c|c|c|c|c|}
\hline \multirow{2}{*}{$\begin{array}{c}\text { MODIS } \\
\text { 8-day } \\
\text { Composite }\end{array}$} & \multicolumn{3}{|c|}{ 2002-03 (Drought year) } & \multicolumn{3}{|c|}{ 2003-04 (Normal year) } & \multicolumn{3}{|c|}{ 2004-05 (Normal year) } \\
\hline & $\begin{array}{c}\text { AET } \\
(\mathrm{MCM})\end{array}$ & $\begin{array}{c}\mathrm{OL} \\
(\mathrm{MCM})\end{array}$ & $\begin{array}{c}\text { C S T } \\
(\mathrm{MCM})\end{array}$ & $\begin{array}{c}\mathrm{AET} \\
(\mathrm{MCM})\end{array}$ & $\begin{array}{c}\mathrm{OL} \\
(\mathrm{MCM})\end{array}$ & $\begin{array}{l}\text { C S T } \\
(\mathrm{MCM})\end{array}$ & $\begin{array}{c}\text { AET } \\
(\mathrm{MCM})\end{array}$ & $\begin{array}{c}\mathrm{OL} \\
(\mathrm{MCM})\end{array}$ & $\begin{array}{c}\text { C S T } \\
(\mathrm{MCM})\end{array}$ \\
\hline $1,2,3$ & & & 0.256 & & & 18.165 & & & 20.936 \\
\hline 31-Oct & 0.04 & 0.19 & 0.215 & 1.64 & 16.37 & 18.009 & 2.32 & 18.44 & 20.761 \\
\hline 08-Nov & 0.04 & 0.18 & 0.202 & 1.58 & 15.91 & 17.488 & 1.86 & 18.32 & 20.174 \\
\hline $16-\mathrm{Nov}$ & 0.04 & 0.16 & 0.182 & 1.67 & 15.60 & 17.271 & 1.67 & 18.26 & 19.931 \\
\hline 22-Nov & 0.04 & 0.13 & 0.158 & 1.51 & 15.53 & 17.037 & 1.77 & 17.90 & 19.667 \\
\hline 02-Dec & 0.04 & 0.12 & 0.145 & 1.31 & 15.71 & 17.018 & 1.78 & 17.87 & 19.645 \\
\hline 10-Dec & 0.02 & 0.12 & 0.134 & 1.69 & 15.10 & 16.789 & 1.84 & 17.54 & 19.388 \\
\hline 18-Dec & 0.02 & 0.10 & 0.118 & 1.52 & 14.25 & 15.767 & 1.99 & 16.25 & 18.237 \\
\hline 26-Dec & 0.03 & 0.07 & 0.091 & 1.77 & 13.62 & 15.388 & 2.10 & 15.72 & 17.811 \\
\hline 01-Jan & 0.03 & 0.06 & 0.080 & 1.62 & 13.57 & 15.185 & 2.59 & 14.99 & 17.583 \\
\hline 09-Jan & 0.02 & 0.05 & 0.063 & 1.43 & 13.46 & 14.894 & 2.85 & 14.40 & 17.254 \\
\hline 17-Jan & 0.01 & 0.04 & 0.052 & 1.53 & 12.57 & 14.106 & 2.52 & 13.85 & 16.367 \\
\hline 25-Jan & 0.02 & 0.03 & 0.040 & 1.59 & 11.89 & 13.473 & 2.65 & 13.01 & 15.654 \\
\hline 02-Feb & 0.02 & 0.02 & 0.031 & 1.83 & 9.93 & 11.769 & 2.07 & 11.66 & 13.735 \\
\hline $10-\mathrm{Feb}$ & 0.02 & 0.01 & 0.026 & 1.85 & 8.87 & 10.724 & 2.41 & 10.15 & 12.559 \\
\hline $18-\mathrm{Feb}$ & 0.02 & 0.00 & 0.017 & 1.81 & 6.78 & 8.584 & 2.65 & 7.49 & 10.147 \\
\hline 26-Feb & 0.02 & 0.00 & 0.010 & 1.60 & 4.71 & 6.308 & 2.95 & 4.63 & 7.582 \\
\hline 06-Mar & 0.01 & 0.00 & 0.005 & 1.94 & 2.60 & 4.541 & 2.18 & 4.09 & 6.265 \\
\hline 14-Mar & 0.01 & 0.00 & 0.004 & 1.44 & 1.73 & 3.165 & 2.12 & 2.51 & 4.634 \\
\hline 22-Mar & 0.00 & 0.00 & 0.00066 & 1.70 & 0.41 & 2.110 & 2.02 & 1.19 & 3.212 \\
\hline 30-Mar & 0.00 & 0.00 & 0.00019 & 0.89 & 0.37 & 1.264 & 1.71 & 0.28 & 1.997 \\
\hline
\end{tabular}

Note: $\mathrm{AET}=$ Actual Evapotranspiration, $\mathrm{OL}=$ Other Loses, $\mathrm{CST}=$ Change in Storage, $\mathrm{MCM}=$ Million Cubic Meter, LISS-III data of $1=10 / 10 / 2002,2=20 / 10 / 2003$ and $3=14 / 10 / 2004$ as reference storage 


\section{CONCLUSIONS}

Following conclusions are drawn from the present study.

- The present study shows that various indices derived using multi spectral data can be used to map lake structural components like open-water, emergent vegetation with good accuracy.

- This paper highlights a methodology to derive depth contours of the lake using limited GPS based observation based on water spread extent observed in remote sensing data.

- $\quad$ SRTM DEM calibrated with known elevation points was useful in assessing the optimum storage requirement of the lake for avifauna habitat.

- High temporal MODIS data is useful in monitoring two important structural components viz open-water and emergent vegetation, which show a strong relationship to avifauna habitat of the Nalsarovar lake.

- The lake registered a significant change in the extent of open-water and emergent vegetation due to seasonal change within a year.

- Water extent at about $9 \mathrm{~m}$ elevation at the end of the rainy season is found to be optimal for maintaining various habitats that in turn support the avifauna for the rest of the lean period.

\section{REFERENCES}

Anon. (1998). Environmental impact assessment of Sardar Sarovar project on Nalsarovar Bird Sanctuary. EIA/9/98. A Technical Report: Gujarat Ecological Education and Research (GEER) Foundation, Gandhinagar, India

Anon. (2005). NNRMS Standards, A National standard for EO images, thematic and cartographic maps, GIS databases and spatial outputs.ISRO: TR: 112:2005. A committee Report: National Natural Resources Management System, Bangalore, India.

Bhattacharya, B.K., Vyas, S. P., Dutta, S., Patel, N.K., Parihar, J.S. and Mallick, K. 2007. Regional evapotranspiration estimation and wheat yield Prediction using Satellite data. EOAM/SAC/GEWBS/SN/08/2007. A Scientific Report: Space Applications Centre, Ahmedabad, India.
Hanqiu, Xu, 2002. Spatial expansion of urban/town in Fuqing of China and its driving force analysis. Remote Sensing Technology and Application, 17, pp. 86-92.

Lacaux, J.P., Tourre, Y.M., Vignolles, C., Ndione, J.A. and Lafaye, M. (2007). Classification of ponds from high-spatial resolution remote sensing: Application to Rift valley fever epidemics in Senegal. Remote Sensing of Environment, 106, pp. 66-74.

McFeeters, S.K. (1996). The use of Normalised Difference Water Index (NDWI) in the delineation of open-water features. International Journal of Remote Sensing, 17, pp. 1425-1432.

Mitsch, W.J. and Gosselink, J.G. (2000). Wetlands. (New York: John Wiley \& Sons), P. 920.

Murthy, T.V.R., Patel, J.G., Singh, T.S., Suthar, N.M. and Sushma Panigrahy (2009). Application of RS data based Spectral Indices for Wetland Inventory and Assessment. Proc. National Symposium on "Advances in Geo-spatial Technologies with Special Emphasis on Sustainable Rainfed Agriculture" and Annual Convention of Indian Society of Remote Sensing (ISRS). September 17-19, 2009. Nagpur, India

Ndirima, Z.K. (2007). Mapping and monitoring wetland vegetation used by Wattled Cranes using remote sensing: Case study of Kafue Flats, Zambia. M.Sc. Thesis, ITC, The Netherlands

Prigent, C., Matthews, E., Aires, F. and Rossow, W.B. (2001). Remote sensing of global wetland dynamics with multiple satellite datasets, Geophysical Research Letters, 28, pp. 46314634 .

Tatu, K. 1995. Ecological study of Nalsarovar (Gujarat) with an emphasis on its floristic \& avifaunal profile using satellite remote sensing technique, Ph.D.Thesis, Gujarat University, Ahmedabad, India.

Townshend, J.R. and Justice, C.O. (1986). Analysis of dynamics of African vegetation using the Normalised Difference Vegetation Index. International Journal of Remote Sensing, 7, pp. 1435-1445.

Tucker, C.J. and Sellers, P.J. 1986. Satellite remote sensing of primary productivity. International Journal of Remote Sensing, 7, pp. 1395-1416.

\section{ACKNOWLEDGEMENTS}

Authors are thankful to Dr. R.R. Navalgund, Director, Space Applications Centre, and Dr. J.S. Parihar, Dy. Director, EPSA/SAC for their support and guidance provided during this study. 